\title{
Technology Shocks in Multi-Sided Markets: The Impact of Craigslist on Local Newspapers ${ }^{*}$
}

\author{
Robert Seamans \\ Stern School of Business \\ New York University \\ rseamans@stern.nyu.edu
}

\author{
Feng Zhu \\ Marshall School of Business \\ University of Southern California \\ fzhu@marshall.usc.edu
}

February 6, 2012

*We thank Victor Bennett, Kevin Boudreau, Ambarish Chandra, Shantanu Dutta, J. P. Eggers, Lapo Filistrucchi, Lisa George, Anindya Ghose, Avi Goldfarb, Shane Greenstein, Marvin Lieberman, Geoffrey Parker, Henning Piezunka, Qiaowei Shen, Anand Swaminathan, Monic Sun, Catherine Tucker, and participants at the 2010 NYU Stern Economics of Strategy conference, the 2010 ICT-Growth Conference at Ludwig Maximilian University, the 2010 NET Institute Conference, the 2011 International Industrial Organization Conference, the 2011 Atlanta Competitive Advantage Conference, the 2011 NBER Summer Institute, the 9th West Coast Research Symposium on Technology Entrepreneurship, the 9th ZEW Conference on the Economics of ICT and the 2011 Columbia Business Strategy Conference for valuable feedback. We are grateful to the NET Institute, www.NETinst.org, for financial support. 


\title{
Technology Shocks in Multi-Sided Markets: The Impact of Craigslist on Local Newspapers
}

\begin{abstract}
We investigate the impact of Craigslist, a website providing classified-advertising services, on local newspapers' pricing strategies. We exploit temporal and geographic variation in Craigslist's entry to show that newspapers with greater reliance on classified-ad revenue experience a larger drop in classified-ad rates after Craigslist's entry. The impact of Craigslist's entry propagates to the subscriber and display-ad sides of these newspapers: Relative to other newspapers, they experience an increase in subscription prices, a decrease in circulation shares, and a decrease in display-ad rates. These findings are consistent with a model that treats the newspaper industry as a three-sided market.
\end{abstract}

\section{Introduction}

The fate of traditional media, such as radio, TV, and newspapers, has received much attention since the advent of the Internet (e.g., Athey et al. 2010). On one hand, the number of voices warning of traditional media's demise has increased over the years, given the growing popularity of online media. On the other hand, traditional media have in the past survived threats from, and learned to coexist with, new technologies. For instance, the newspaper industry successfully responded to threats from new technologies such as radio in the 1920s and TV in the 1950s (e.g., Jackaway 1995). Quantifying the Internet's impact on traditional media is difficult for several reasons. First, the Internet's diffusion is likely to be correlated with many macro trends (e.g., Forman, Goldfarb and Greenstein forthcoming) that also affect demand for traditional media. Second, traditional media such as newspapers serve both consumers and advertisers, and products or services available on the Internet may affect these sides of the market in different ways. For example, social media, such as blogs and video-sharing sites, draw consumers away from traditional media and the low costs of online advertising reduces the attractiveness of traditional media to advertisers. It is therefore difficult to link responses by traditional media firms to the diverse mechanisms through which the Internet affects traditional media.

In this study, we take advantage of the temporal and geographic variation in entry by Craigslist, a website providing classified-ad services, to examine its impact on local US newspapers. Craigslist offers 
classified ads for free in most cases. ${ }^{1}$ In addition, ads on Craigslist are easy to search and are updated in real time, unlike a newspaper. We therefore expect Craigslist's entry to significantly reduce newspapers' attractiveness to classified-ad buyers and thus reduce newspapers' classified-ad rates. We adopt a difference-in-differences approach that compares local newspapers for which classified ads are likely to be a significant fraction of revenue to other newspapers before and after Craigslist's entry. We identify such newspapers by whether or not they have a classified-ad manager. We find that these newspapers drop their classified-ad rates more than other newspapers following Craigslist's entry.

Newspapers are platforms that link together three different groups: subscribers, classified-ad buyers, and display-ad buyers. ${ }^{2}$ We therefore next examine how the impact of Craigslist's entry on the classified-ad side propagates to the other two sides of the market. We find that, following Craigslist's entry, newspapers with classified-ad managers increase subscription prices relative to newspapers without classified-ad managers. As a result, their circulation shares drop more. Because of the drop in circulation shares, their display-ad rates also decrease more following Craigslist's entry. We provide a number of robustness checks to rule out alternative explanations. In particular, we find no evidence that the content of affected newspapers changes with Craigslist's entry, which helps rule out a change in newspaper targeting as an alternative explanation to our findings. Finally, we link our findings together with a model that treats the newspaper industry as a three-sided market and illustrates how the impact of entry by an online competitor on the classified-ad side propagates to the subscriber and display-ad sides.

Our study contributes to several streams of research. First, we add to a nascent stream of research on multi-sided markets (e.g., Caillaud and Jullien 2003; Rochet and Tirole 2003; Parker and Van Alstyne 2005; Armstrong 2006; Hagiu 2006; Weyl 2010). Much of this literature studies competition between platforms (e.g., Casadesus-Masanell and Ghemawat 2006; Economides and Katsamaks 2006), the platform provider's decision about how much to open its platform to create a platform ecosystem (Boudreau and Lakhani 2009; Boudreau 2010; Boudreau forthcoming; Ceccagnoli, Forman, Huang and Wu 2012; Huang, Ceccagnoli, Forman and Wu 2011) and platform providers' optimal choices of business models (e.g., Chen, Fan and Li 2011).

More recent theoretical work in this area studies competition on one side of a platform's market and finds that an increase in competition on one side can lead to an increase in price on the other side (Godes et al. 2009; Hagiu 2009). The intuition is that platforms can under-price to the consumer side to attract more consumers, thereby increasing advertiser willingness to pay. Platforms have incentive to do

\footnotetext{
${ }^{1}$ Craigslist charges for job listings in a small number of cities, and for apartment listings in New York City. Source: http://www.craigslist.org/about/factsheet, accessed May 2011.

${ }^{2}$ Businesses use display ads, which often contain graphics or other artwork, to promote their products and services; such ads are displayed alongside regular editorial content. In contrast, classified ads typically have no pictures or other graphics. They are grouped entirely in a distinct section. In the classified-ads section, ads are usually grouped under headings classifying the products or services, such as Automobiles, For Sale, and For Rent.
} 
this when the increased profits from the advertiser side more than make up for the lost profits on the consumer side. However, when competition on the advertising side of the market increases, the number of advertisers available to the incumbent platform drops. When the number of advertisers per incumbent decreases, incumbent platforms have less incentive to under-price content to the consumer side.

Anecdotal evidence supports this theoretical prediction. Most newspaper websites in the 1990s, for example, offered their content for free and financed themselves exclusively by advertising revenues. As the number of online content sites increased, many newspaper websites, such as the website of the New York Times, have switched to subscription-based business models (Casadesus-Masanell and Zhu 2010). ${ }^{3}$ Few studies except Jin and Rysman (2010) provide direct tests of this prediction. ${ }^{4}$ Jin and Rysman (2010) study sportcards conventions and show that prices to consumers drop but prices to dealers may increase as competition between platforms (the conventions) increases. The direction of price changes hinges on the relative intensity of competition on each side of the market. Jin and Rysman's setting allows them to use variation in geographic distance between conventions to infer an asymmetric degree of competition for consumers and dealers.

Our study complements Jin and Rysman's in several respects. First, Craigslist's entry directly affects only one side of the newspaper's market because Craigslist provides classified ads and not editorial content. Hence our empirical analysis provides a sharp test of how increased competition on one side of the market affects other sides. Second, our analysis shows that the direction of price change in a three-sided market depends on the interdependency across different sides. In our setting, the display-ad side does not interact directly with the classified-ad side; they are linked to each other through the subscriber side. Display-ad rates drop as an indirect result of increased competition on the classified-ad side. Finally, our study employs a difference-in-differences research design that uses panel data on newspapers together with Craigslist's geographical and temporal entry patterns. This research design helps rule out multiple alternative explanations.

Our study contributes to a second stream of literature that examines how the Internet affects firms and consumers in offline settings. At a broad level, a number of studies have argued that online intermediaries reduce buyer search costs, thereby improving the efficient matching of buyers and sellers (e.g., Bakos 1997; Kroft and Pope 2008). Studies in a variety of contexts have examined whether online and offline channels substitute or complement each other (e.g., Zentner 2005; Kaiser 2006; Gentzkow 2007; Simon and Kadiyali 2007; Forman, Ghose, and Goldfarb 2009; Choi and Bell 2011; Goldfarb and

\footnotetext{
${ }^{3}$ For other examples, see http://paidcontent.org/article/419-taking-the-plunge-how-newspaper-sites-that-charge-arefaring/, accessed August 2011, for a partial list of newspaper sites charging fees to readers.

${ }^{4}$ Much of the empirical literature on multi-sided markets focuses on quantifying indirect network effects in these markets (e.g., Nair et al. 2004; Kaiser and Song 2009; Wilbur 2008), evaluating exclusive contracting between platforms and application developers (e.g., Corts and Lederman 2009), and examining conditions under which tipping occurs (e.g., Cantillon and Yin 2008).
} 
Tucker 2011a, 2011b; Liebowitz and Zentner forthcoming). Studies have also shown that the reduction of search cost owing to the advent of online channels may reallocate market shares from high- to low-cost producers (Goldmanis et al. 2010). Our study complements these studies by examining how the diffusion of the Internet affects newspapers' pricing decisions. Our finding that Craigslist leads to a significant reduction in newspapers' classified-ad rates suggests that Craigslist acts as a substitute for newspapers' classified services.

Finally, this study adds to the literature on media firms' responses to competition. Scholars examine how media firms adjust prices in response to changes in competition (e.g., Chandra and CollardWexler 2009). A few studies also study how media firms change their content to do better targeting as a result of competition (e.g., George and Waldfogel 2006; Chandra 2009) or consolidation (e.g., Berry and Waldfogel 2001; George 2002, 2007; Sweeting 2010). Our study of Craigslist's entry differs in that competition is intensified mostly on the classified-ad side of the market. In addition, we find that the newspapers for which classifieds are important do not appear to target new audiences in response to Craigslist's entry, indicating that newspapers' main response is to change pricing, rather than to change content.

The rest of the article is organized as follows. Section 2 presents background information on Craigslist. Section 3 describes our data. Section 4 presents results from our empirical analyses, including robustness checks. Section 5 presents a simple model of a three-sided market that illustrates how the impact of Craigslist's entry in the classified-ad side of the newspaper market propagates to the subscriber and display-ad sides. We conclude in Section 6.

\section{Background on Craigslist}

Craigslist is a website that specializes in online classified listings. It began its service in 1995 as an email distribution list of friends in the San Francisco Bay Area, before becoming a web-based service in 1996. Craigslist expanded into eight more US markets in 2000, four in 2001 and 2002 each, twelve in 2003, and many more markets in recent years (see Figure 1). ${ }^{5}$ It selects markets based on the number of user requests for the market, and as of 2010 Craigslist is available for more than 700 local markets in 70 countries. ${ }^{6}$ Craigslist serves over twenty billion page views per month, and is the 7 th most-visited web site in the United States. ${ }^{7}$ With over fifty million new classified advertisements each month, ${ }^{8}$ as well as

\footnotetext{
${ }_{6}^{5} \mathrm{http}: / /$ www.craigslist.org/about/expansion, accessed July 2010.

${ }^{6} \mathrm{http} / / / \mathrm{www}$. craigslist.org/about/factsheet, accessed July 2010.

7 http://www.alexa.com/siteinfo/craigslist.org, accessed July 2010.

${ }^{8}$ http://www. craigslist.org/about/factsheet, accessed July 2010.
} 
about sixty million unique visitors in the US each month, ${ }^{9}$ Craigslist is the leading classified-ad service in any medium.

Historically, revenues from classified ads account for $40 \%$ of a newspaper's total revenues on average (Vogel 2011). ${ }^{10}$ Hence, the introduction of Craigslist into a newspaper's local market has the potential to be incredibly disruptive, leading to an almost immediate drop in a large portion of revenue. Indeed, Craigslist has been criticized for stealing a massive chunk of the classified market from established local newspapers and is frequently referred as a "newspaper killer."11 Craigslist's entry into different markets has also led to other unintended consequences. For example, Chan and Ghose (2011) show that Craigslist's entry into a market is associated with an increase in sexually transmitted diseases in that market.

Our empirical setting provides several advantages for examining newspapers' responses to increased competition. First, temporal and geographical variation in the expansion of Craigslist into different markets allows us to establish a causal relationship. The environment is a complex one: Many technological changes, the diffusion of the Internet in particular, have affected the newspaper industry. For example, websites such as eBay.com, an online auction site, and monster.com, a job-listing website, attract classified advertisers away from newspapers, and content sites, such as blogs and Google news, attract newspaper readers away from newspapers. Unlike Craigslist, these sites contemporaneously serve consumers in all regions in the US. In our setting, we are able to use year dummies and their interactions with newspaper types to control for the overall effects these types of websites have on newspapers as well as the disproportionate effects these websites have on different types of newspapers.

Second, Craigslist is a competitor that provides only classified-ad listings, not editorial content or display ads. Hence, entry by Craigslist directly affects the newspaper's classified-ad business but does not directly affect its subscribers or display-ad buyers. Our empirical setting therefore closely matches the conditions described in theoretical work that studies how an increase in competition on one side of the market may increase price on the other side.

Third, we are able to collect price data on all three sides of the newspaper market. One of the empirical challenges associated with studying multi-sided markets is collecting price data on all sides of the market. For example, video games are a canonical example of a two-sided market, but researchers do not observe the contractual agreements on royalty rates between console providers and game publishers.

\footnotetext{
${ }^{9} \mathrm{http}: / /$ siteanalytics.compete.com/craigslist.org/, accessed July 2010.

${ }^{10}$ See also: Swarts, Will. "Craigslist: Stopping the Presses?" at Smart Money, September 7, 2005. Source: http://www.smartmoney.com/investing/stocks/craigslist-stopping-the-presses-18189/, accessed July 2011.

${ }^{11}$ See, for example, http://www.sfbg.com/40/18/x_editors_notes.html, http://nymag.com/nymetro/news/media/internet/15500/, http://sfist.com/2004/12/29/craigslist_newspaper_killer.php, and http://www.forbes.com/2006/12/08/newspaper-classifield-online-tech_cx-lh_1211craigslist.html, accessed July 2011.
} 
Finally, Craigslist's product is similar across markets in a given year, making it easy to compare entry events. The Craigslist webpage for Boston in February 2003, for example, is nearly identical to that for Chicago in February 2003 (see Figures 2 and 3). One noticeable difference across these web pages is the number of posts in each category, perhaps indicating heterogeneity in demand for Craigslist's product across these markets. In the results section below we show that our findings are robust to controlling for these cross-market differences.

\section{Data}

We collect data from several sources. Information on the date of Craigslist's entry into different markets is from Craigslist. During the time period we study, Craigslist enters 278 markets. ${ }^{12}$ Using this information, we create a dummy variable craigslist_entry ${ }_{i t}$ that equals one for all years after Craigslist enters the newspaper's local market, and zero otherwise. We define the relevant market to be the county in which the newspaper is based, an approach consistent with other research in this area (e.g., Gentzkow and Shapiro 2010) and consistent with Craigslist's product offerings, which sometimes vary by county or by state region. ${ }^{13}$ For example, Craigslist has separate pages for La Salle County, Illinois; Fairfield County, Connecticut; Western Maryland; and Eastern North Carolina, to name a few. Information on classified-ad rates is from the SRDS Newspaper Advertising Source (SRDS) for years 1999-2006. SRDS has been used in other media studies (e.g., Ekelund et al. 2000).

Information on each newspaper's yearly circulation, subscription price, display-ad rate, year founded, political leaning, and editor or ad-manager type is from Editor \& Publisher International Yearbooks (E\&P) for years 1998, 1999, 2001, 2003, 2004, 2005, 2006 and 2008. Information published in these yearbooks is current as of the year prior to publication. The yearbooks contain data on virtually every newspaper in the US, and have been used extensively for newspaper studies (e.g., George and Waldfogel 2006; Chandra 2009; Gentzkow and Shapiro 2010). Such data are also used by the US census to compile summary statistics for the annual Statistical Abstract of the United States.

We construct the variable classified $_{i t}$ from a field that lists positions in the advertising-sales management team. If one or more positions include the word "classified," we code classified $_{i t}$ as one; otherwise we code it as zero. ${ }^{14}$ We use this variable to indicate those newspapers that rely heavily on classified ads, and hence we expect those newspapers to be significantly affected by Craigslist's entry.

\footnotetext{
${ }^{12}$ The company lists the dates and locations of its expansion here: http://www. craigslist.org/about/expansion. From November 2006, the site lists only the number of cities entered, so we supplement with information from older Craigslist websites found on the Internet Archive.

${ }^{13}$ The relevant newspaper market has been alternately defined at other levels including the zip code (Chandra, 2009) and MSA (George and Waldfogel, 2006).

${ }^{14}$ Examples of other position titles include: Advertising Department Manager, Advertising Sales Director, Retail Sales Manager, Advertising Coordinator for Special Sections, and Advertising Manager for Major Accounts.
} 
The dummy variable independent ${ }_{i}$ equals one if the newspaper's politics in 2005 is listed as independent, and zero otherwise. ${ }^{15}$ The continuous variable newspaper_age $e_{i t}$ is the difference between the year in the sample and the year the newspaper was founded. Information about the newspaper's editors was collected to create shares of editor types. We accomplish this by categorizing each editor's title into one of the following types: art, business, entertainment, home, local, national, opinion, special, sports, and technology. Shares have been created for each newspaper and year by summing the number of editors under each type and dividing by the total number of editors. To measure newspapers' content variety, we also construct a variable total_positions $s_{i t}$, which is the total number of editor types at a newspaper. We also construct the variable number MIS positions $_{i t}$ which is a count of the number of positions listed under the employment category Management Information Systems (MIS)/Interactive Services.

We collect demographic data on age $_{i}$, population $_{i}$, pct_college_degree $_{i}$, per_capita_income $_{i}$ and pct_renters $_{i}$ at the county level for the year 2000 from the US Census Bureau. ${ }^{16}$ Following George and Waldfogel (2006), we use the population data as a denominator to transform the circulation variable into circulation share, and use it as one of our dependent variables. We also collect information on the number of high-speed internet service providers (ISPs) at the zip code for 2000-2007 from the Federal Communications Commission (FCC). ${ }^{17}$ This information is then averaged across all zip codes in the county. The population data are used as a denominator to transform the number of ISPs in the county into the variable average_ISPs $s_{i t}$. Wallsten and Mallahan (2010) show that the number of ISPs in a market is positively correlated with broadband quality and negatively correlated with broadband price. Hence, this variable is included to control for diffusion of the Internet within the relevant market, which may affect newspapers' strategies.

We use internetarchive.org to access historical pages of Craigslist for each year for all of the markets in our sample, and from these pages, we gather counts of the number of posts in each category. For example, in Boston on February 7, 2003 under the category "sale/wanted," there were 2,725 posts listed under "general for sale" and 730 posts listed under "items wanted" (see Figure 2). These category counts are then aggregated up to the market level to create a variable number_of_posts $s_{i t}$, which we use in the robustness checks described below. Over the years, Craigslist has added new categories, such as personals. To ensure that we can compare the number of posts on Craigslist in different years, we only aggregate counts in four categories (community, housing, jobs, and sales/wanted) that Craigslist has had since its inception. When internetarchive.org archives the same Web page multiple times in a single year, we take the average of these counts across the year.

\footnotetext{
${ }^{15}$ We construct this variable using data from 2005 only. There is no evidence that a newspaper's political leaning changes over our time period.

${ }^{16}$ Available for download from the US Census Bureau at http://factfinder.census.gov, last accessed May 2011.

${ }^{17}$ Available for download from the FCC at http://www.fcc.gov/wcb/iatd/comp.html, last accessed May 2011.
} 
Summary statistics of all variables used are provided in Table 1. Table 2 provides additional summary statistics for classified-ad rates, subscription prices, circulation shares, and display-ad rates before and after Craigslist's entry, broken out separately for newspapers with and without a classified editor. There is substantial variation across newspapers for each of these four measures (see Table 1), which is addressed using newspaper fixed effects in the econometric models discussed below. To address this heterogeneity in Table 2, before computing their averages, we standardize these measures (to measures with mean 0 and standard deviation 1) for each newspaper. We compute the summary statistics for newspapers with and without a classified-ad manager in the year of Craigslist's entry separately. We find that classified-ad rates, subscription prices, and display-ad rates increase for newspapers over time, but that circulation shares decrease over time. We also compute the changes for newspapers before and after Craigslist's entry and compare newspapers with classified-ad managers in Craigslist's entry year to those without. We find that those newspapers which are more likely to be affected by Craigslist's entry have greater decreases in classified-ad rates, circulation shares, and display-ad rates, as well as greater increases in subscription prices. The differences are significant for all measures except for display-ad rates in one-sided t-tests.

\section{Empirical Analysis}

\subsection{Impact of Craigslist's Entry}

We first focus on the effect of Craigslist's entry on classified-ad rates. The empirical design relies on a difference-in-differences approach that compares classified-ad rates after Craigslist's entry to rates before Craigslist's entry for newspapers with and without a classified-ad manager. The specification is of the following form:

(1) rate $_{i t}=\beta_{0}+\beta_{1}$ craigslist $_{i t}+\beta_{2}$ craigslist $_{i t}{ }^{*}$ classified $_{i t}+\beta_{3}$ classified $_{i t}+X_{i t} B+\gamma_{i}+\eta_{t}+\varepsilon_{i t}$,

Rate $_{i t}$ is the classified-ad rate, $X_{i t}$ is a vector of other market control variables, $\gamma_{i}$ is a newspaper fixed effect, and $\eta_{t}$ is a year fixed effect. Inclusion of the newspaper fixed effect controls for any fixed differences across newspapers, and the year dummies control for common macroeconomic shocks that affect all newspapers. Some macroeconomic shocks (e.g., the diffusion of monster.com, a job-listing website) may differentially affect newspapers with different degrees of reliance on classified-ad business. We therefore include interactions between classified $_{i t}$ and year dummies in $X_{i t}$. These interaction variables also help control for any pre-existing trends. We also include a count of the number of Internet service providers in the market, average_ISPs $s_{i t}$ in $X_{i t}$ to address changes in the relative ease of Internet access, which might affect a local newspaper's classified-ad business. We cluster the error terms at the level of 
the newspaper to account for autocorrelation in the data across newspapers and over time (Bertrand et al. 2004).

Table 3 reports regression results on log classified-ad rates. All models include newspaper and year fixed effects. Model 1 includes the dummy variable for craigslist_entry $y_{i t}$ and a dummy for classified $_{i t}$, neither of which is significant. Model 2 replicates Model 1 and adds an interaction between classified $_{i t}$ and craigslist_entry $_{i t}$. The coefficients on craigslist_entry $_{i t}$ and classified $_{i t}$ remain insignificant, whereas the coefficient on their interaction is negative and significant. This result indicates that newspapers with classified-ad managers are, on average, more likely to lower classified-ad rates following entry by Craigslist. Model 3 replicates Model 2 and adds the interactions between year dummies and classified $_{i t}$. Model 4 replicates Model 3 and adds average_ISPs $_{i t}$ as an additional control; there are fewer observations in this subsample because average_ISPs $s_{i t}$ is only available after 1999. The results across models are broadly similar; namely, newspapers with classified-ad managers are, on average, more likely to lower classified-ad rates (by about $20.7 \%$ based on Model 4 ) following entry by Craigslist.

We next investigate how the effect of Craigslist's entry propagates to the subscriber side and the display-ad side. This is accomplished by replacing classified-ad rate as the dependent variable in (1) with: newspaper's subscription prices, circulation shares, and display-ad rates. We replicate Models 3 and 4 from Table 3 (i.e., with and without average_ISP $s_{i t}$, respectively) and report the results in Table 4. We find that the coefficient on classified $_{i t}{ }^{*}$ craigslist_entry $_{i t}$ is significant in all models except Model 5, suggesting that Craigslist's entry into the newspaper's classified-ad side does influence the newspaper's subscriber side and display-ad side. In particular, we find that subscription prices of the affected newspapers increase by $3.3 \%$, yearly circulations drop by $4.4 \%$, and display-ad rates drop by $3.1 \%$ (based on Models 2, 4, and 6, respectively). It is worth noting that the magnitudes of the effects presented in Table 4 are small relative to the effects presented in Table 3 . These results accord well with the idea that the direct effect of Craigslist's entry is to the newspaper's classified-ad business, and that Craigslist's entry has an indirect effect on the other sides of the market. In Section 5, we use the findings presented in Tables 3 and 4 to motivate a simple model of how these effects propagate from one side of a market into the others.

\subsection{Robustness Checks}

This subsection outlines potential concerns with our findings and the robustness tests undertaken to address each concern. The first concern we address is the potential endogeneity of Craigslist's entry. Although our fixed-effects specifications control for time-invariant unobservables specific to newspapers and locations, it is still possible that Craigslist's entry decisions may be correlated with some time- 
varying unobservables. We undertake several tests to address this concern and rule out alternative explanations.

First, we take advantage of geographical and temporal variation in Craigslist's entry to directly examine which factors influence Craigslist's entry decisions. The idea is that if these time-varying location-specific unobservables affect both Craigslist's entry decisions and newspapers' characteristics, we should observe correlation between Craigslist's entry decisions and newspapers characteristics. Table 5 presents the results of hazard models that predict Craigslist's entry into a newspaper's market as a function of county demographics in which the newspaper is located, as well as newspaper characteristics. Model 1 of Table 5 includes market characteristics such as age $e_{i}$, population ${ }_{i}$, pct_college_degree $e_{i}$, pct_black $_{i}$,per_capita_income ${ }_{i}$, pct_renters $_{i}$, and average_ISPs $_{i t}$. Model 2 adds in newspaper and market characteristics including number of newspapers ${ }_{i t}$ in the market, independent ${ }_{i}$ and newspaper_age ${ }_{i t}$. Finally, Model 3 adds in additional newspaper characteristics including classified $_{i t}$, number MIS

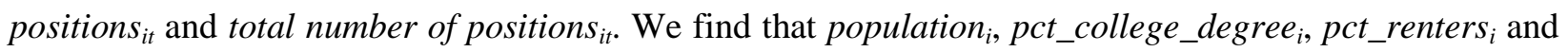
average_ISP $_{i t}$ are significant predictors of Craigslist's entry, and these factors are controlled in the foregoing analyses by the use of fixed effects and inclusion of average_ISPs $s_{i t}$. The results of Table 5 therefore provide us with some confidence that Craigslist's entry decisions are not based on newspaper characteristics, particularly those that vary over time.

Second, we conduct a falsification test using Craigslist's entry patterns to examine the role of location-specific unobservables. We compare pricing strategies of newspapers that would be affected by Craigslist's entry (i.e., those newspapers with classified-ad managers and located in counties Craigslist enters) prior to Craigslist's entry into their markets to the pricing strategies of other newspapers. If our assumption of the orthogonality between Craigslist's entry and time-varying local unobservables is violated in our fixed-effects specifications, our data will produce false positive associations between Craigslist's entry and the pricing strategies of these affected newspapers in periods prior to Craigslist's entry in their markets. To check this, we first create a new variable, eventual_entry, which is one if Craigslist enters location $i$ at any time before 2007, and zero otherwise. We then repeat our difference-indifferences analysis by replacing craigslist_entry ${ }_{i t}$ with eventual_entry $y_{i}$ and only analyzing observations for which craigslist_entry ${ }_{i t}$ is zero. The effect of eventual_entry $y_{i}$ is absorbed by the newspaper fixed effects. As reported in Table 6, we find that there is no significant correlation between each of the four outcome variables, classified_ad_rate ${ }_{i t}$, subscription_price ${ }_{i t}$, circulation_share $_{i t}$, and display_ad_price ${ }_{i t}$, and the interaction between eventual_entry ${ }_{i}$ and classified $_{i t}$ during periods prior to Craigslist's entry. The absence of such false positives further increases our confidence in the exogeneity assumption.

Third, we provide robustness tests that use the number of posts on Craigslist, a continuous variable, in place of the dummy variable, craigslist_entry ${ }_{i t}$. The variable num_craigslist_posts it $_{\text {it }}$ equals 
zero in all years before Craigslist enters a county and is some positive number in each year after Craigslist enters. Table 7 provides regression results for the four outcome variables, classified_ad_rate ${ }_{i t}$, subscription_price $_{i t}$, circulation_share $_{i t}$, and display_ad_price $i_{i t}$. The signs on the coefficient classified $_{i t}{ }^{*}$ craigslist_entry $_{i t}$ match the signs shown in Tables 3 and 4. Thus, whereas heterogeneity in population tastes or in ease of access to the Internet across markets may lead Craigslist to be more popular in some areas than others, the main results hold even when accounting for these factors.

Finally, we note that the concern about endogeneity of Craiglist's entry is somewhat alleviated by the peculiar nature of Craigslist's corporate mission. Craigslist is incorporated as a for-profit company, but it still uses the ".org" domain, whereas a for-profit company would typically use the ".com" domain. According to Craigslist, the company does this because the ".org" domain "symbolizes the relatively noncommercial nature, public service mission, and non-corporate culture of Craigslist." "18 Anecdotal evidence in the popular press provides additional support for the idea that Craigslist may focus on objectives other than profits. For example, in its annual ranking of top private digital companies, Silicon Alley Insider estimates that Craigslist generated about $\$ 150 \mathrm{M}$ in ad revenue in 2009 , but could have generated at least $\$ 1 \mathrm{~B} .{ }^{19}$ Thus, given the anecdotal evidence that the company does not try to maximize profits, but instead some other public service mission-oriented objective, it is plausible that Craigslist's entry into local markets is orthogonal to the financial performance of the newspapers in those markets.

A second potential concern is that the dummy variable classified $_{i t}$ may not accurately capture newspapers' reliance on classified-ad revenue. To address this concern we investigate the correlation between the classified $_{i t}$ variable and the number of pages of classified ads in a newspaper. We accomplish this by hand counting the number of total pages and number of classified advertising pages for a group of newspapers for each quarter from January 1999 to October $2006 .^{20}$ We then create an annual average across the quarters for each newspaper, and regress the annual average classified ad pages on the total number of pages, classified $_{i t}$ and year dummies. The coefficient on classified $_{i t}$ is positive and significant at the 5\% level, indicating a strong correlation between classified $_{i t}$ and the number of advertising pages (see Supplementary Appendix).

We also perform robustness checks with the data to rule out plausible alternative explanations for the result on the classified $_{i t}$ variable. One alternative explanation could be that a large newspaper may have a classified-ad manager even if classified-ad revenue is only a small fraction of its total revenue. To address this concern, we normalize classified $_{i t}$ by the total number of managerial positions each

\footnotetext{
${ }^{18} \mathrm{http}: / /$ www.craigslist.org/about/factsheet, accessed May 22, 2010.

${ }^{19} \mathrm{http://www.businessinsider.com/sai-50-2009 \# 5-craigslist-5,} \mathrm{accessed} \mathrm{August} \mathrm{3,} 2010$.

20 The newspapers, which were chosen because of data availability, include: Albany Times Union, Baltimore Morning Sun, Boston Globe, Cincinnati Enquirer, Cleveland Plain Dealer, Dallas Morning News, Denver Post, Detroit News, Houston Chronicle, Indianapolis Star, Kansas City Times-Star, Louisville Courier Journal, New Orleans Times Picayune, Oregonian, Rochester Democrat and Chronicle, and St. Louis Post Dispatch.
} 
newspaper has on its ad sales team and then repeat the analyses in Tables 3 and 4 . We obtain similar results, which are presented in Table 8.

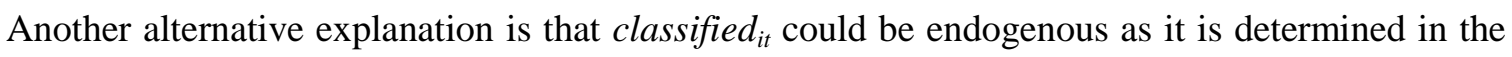
same time period as the pricing variables. In a robustness check, we fix the value of classified $_{i t}$ to its value in 2000. We drop all counties where Craigslist entered on or before 2000 and then run regressions only with observations after 2000. Although the approach does not capture possible shifts in newspapers' reliance on classified-ad revenue, it frees us from the endogeneity concern as the reliance of these newspapers on classified-ad revenue is determined in an earlier period whereas newspaper responses to Craigslist's entry are examined for later periods. The results, presented in Table 9, are similar to those presented in Tables 3 and 4 .

Our third potential concern is the possibility that the observed newspaper responses are a result of other confounding factors. One natural candidate for such a confounding factor is the entry and exit of newspapers which may change the number of competing newspapers that a given newspaper faces. However, the large amount of geographical and temporal variation in Craigslist's entry pattern helps rule out this explanation because it is unlikely that new newspapers systematically enter the market the same time as Craigslist. We conduct a robustness test that includes a count of the number of newspapers in a market (Table 10) and obtain similar results as in Tables 3 and 4.

Another potential candidate for a confounding factor is that the observed responses are a result of newspapers repositioning themselves after Craigslist's entry. Several studies have shown that newspapers may adjust their content in response to competition (George and Waldfogel 2006; Chandra 2009). Following the approach in these studies, we investigate the effect of Craigslist's entry on shares of different types of editors at each newspaper. We present the results of these analyses in Table 11. In Model 1, we examine how Craigslist's entry affects content variety of newspapers by focusing on

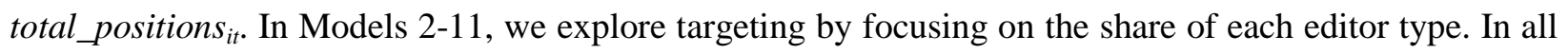
models, the coefficient of the interaction term classified $_{i t}{ }^{*}$ craigslist_entry $_{i t}$ is insignificant, indicating that those newspapers with a classified-ad manager that experience entry by Craigslist behave no differently in setting their content than other newspapers. Hence, there is little evidence that any of the responses by these affected newspapers are driven by content shifts.

\section{A Simple Model}

In this section, we present a stylized model to study the impact of Craigslist's entry into newspaper markets. The purpose of the model is to show that our empirical findings can be predicted from a model with a set of simple assumptions. Since Craigslist only attracts away classified advertisers 
from newspapers, our model focuses its impact on newspapers for which classified-ad revenue is an important revenue source.

Consider a situation where a newspaper charges a fixed fee of $\alpha$ to each classified advertiser, $\beta$ to each display advertiser and $p$ to each subscriber. For simplicity, we assume the marginal cost the newspaper incurs on each side of the market to be zero.

On the subscriber side, we assume that the market size is $S$ and the demand for the newspaper, i.e., circulation, is $D=S-p$. Hence, the newspaper subscription profit will be $D p$. Similar to Armstrong (2006), our functional form implicitly assumes that newspaper demand is independent of the number of ads in the newspaper. This assumption is consistent with empirical findings in Argentesi and Filistrucchi (2007).

When Craigslist is available in the market, classified advertisers have an additional channel to reach consumers. Craigslist is free and posting an ad on Craigslist requires little effort. In addition, Craigslist allows classified advertisers to reach many potential customers who are not newspaper readers. As a result, we assume that all classified advertisers will adopt Craigslist after its entry. Let $\lambda$ be the fraction of the newspaper subscribers who will use Craigslist after its entry. $\lambda$ thus measures the penetration of Craigslist. Before Craigslist's entry, $\lambda=0$; after Craigslist's entry, $\lambda \in(0,1]$. Hence, if the newspaper circulation is $D$, classified advertisers are reaching $(1-\lambda) D$ new consumers by advertising to the newspaper. As the demand from classified advertisers increases with the number of new customers they can reach, similar to Parker and Van Alstyne (2005), we assume the demand function to be $m(1-\lambda) D-\alpha$, where $m>0$ is a constant and measures the extent to which classified advertisers care about the subscriber base of the newspaper. The newspaper profit from classified ads is thus $\alpha(m(1-\lambda) D-\alpha)$.

The setup is similar on the display advertiser side. Assume the demand of display advertisers is $n D-\beta$, where $n>0$ is a constant. We similarly obtain the newspaper profit from display advertisers as $\beta(n D-\beta)$.

The total profit of the newspaper is thus:

$$
\pi(\alpha, \beta, p)=D p+\alpha(m(1-\lambda) D-\alpha)+\beta(n D-\beta),
$$

where $D=S-p$. The newspaper maximizes its profit by setting $p, \alpha$ and $\beta$ simultaneously. Taking the first-order conditions with respect to $p, \alpha$ and $\beta$, we have in equilibrium: 


$$
p=S\left(1-\frac{2}{4-n^{2}-m^{2}(1-\lambda)^{2}}\right), \alpha=\frac{m S(1-\lambda)}{4-n^{2}-m^{2}(1-\lambda)^{2}} \text { and } \beta=\frac{n S}{4-n^{2}-m^{2}(1-\lambda)^{2}} \cdot{ }^{21}
$$

The equations are intuitive. As classified advertisers or display advertisers care more about the number of subscribers of the newspaper (i.e., $m$ or $n$ increases), it is optimal for the newspaper to lower the subscription price, $p$, to increase the number of subscribers, and charge higher rates, $\alpha$ and $\beta$, to the classified and display advertisers.

Comparing to the case without Craigslist (i.e., $\lambda=0$ ), after Craigslist's entry $(\lambda>0)$, we find that subscription price, $p$, increases, and $\alpha$ and $\beta$ decrease. In addition, we find that the newspaper circulation, the number of classified advertisers and the number of display advertisers all decrease with $\lambda$.

These results help interpret our empirical findings. They suggest that as Craigslist's entry decreases the attractiveness of a newspaper to classified advertisers, which now have an alternative channel to reach newspaper subscribers, the newspaper decreases the classified-ad rate. At the same time, as the newspaper no longer finds it as attractive as before to enlarge its circulation, it has a lower incentive to subsidize the subscriber side, and the subscription price increases. The increase in the subscription price in turn leads to lower circulation, making the newspaper less attractive to display advertisers. The display-ad rate drops as a consequence.

Our results build on existing literature on multi-sided markets (Godes et al. 2009; Jin and Rysman 2010) to show that in a multi-sided market setting, an increase in competition on one side does not necessarily increase prices on other sides. The direction of a price change depends on the interdependency across different sides. In our case, the display-ad side does not interact directly with the classified-ad side. Instead, they are linked to each other through the subscriber side.

\section{Discussion and Conclusion}

Our study quantifies the impact of Craigslist on local newspapers in the United States. We provide evidence that the effect of Craigslist's entry on newspapers with classified-ad managers leads to a decrease of $20.7 \%$ in classified-ad rates, an increase of $3.3 \%$ in subscription price, a decrease of $4.4 \%$ in circulation, and a decrease of $3.1 \%$ in display-ad rates. The responses are consistent with a model of a three-sided market.

\subsection{Managerial Implications}

Our study illustrates the challenges faced by platforms in multi-sided markets. First, as different sides of a platform's market are often interdependent with each other, changes on one side of the market

\footnotetext{
${ }^{21}$ In our empirical setting, all prices are positive. Therefore, we consider only the case where $p>0, \alpha>0$ and $\beta>0$ here. This is equivalent to assume that $n^{2}+m^{2}(1-\lambda)^{2}<2$.
} 
tend to propagate to other sides. As a result, platforms need to be cognizant of the multi-sidedness of their markets and consider all sides together when designing optimal strategies. Conventional wisdom from one-sided markets may be misleading in multi-sided markets. As we illustrate empirically in our study, sometimes a platform needs to increase its price on one side of its market as an optimal response to increased competition on another side.

Second, optimal strategies in one multi-sided market setting may not be immediately applicable to another multi-sided market setting. While we provide a three-sided model for the newspaper market, other multi-sided markets may involve different types of participants with different interdependencies across the different sides of the market. For example, social networking sites such as Facebook typically have users, application developers and advertisers as different sides of their markets. As a result, optimal strategies used by newspaper firms to respond to online competition may not be the same for social networking sites. Platforms in other markets thus need to develop deep understanding of the nature of their business models, and then follow our approach to gain insights into their optimal strategies.

Our work also provides empirical evidence that the Internet has substantial impact on offline media firms. Offline media firms are not only affected by online content providers such as blogging sites and video-sharing sites that provide similar content, but are also affected by online service providers that compete away advertisers. More generally, our study helps build an understanding of how media platforms respond to technologically disruptive entrants from different industries. This issue is important because the boundaries between media industries are blurred today, as advertisers can reach relevant consumers through a variety of channels such as TV, the Internet, and mobile devices. Therefore, platforms are likely to be unprepared for competition if they rely on industry boundaries to identify their competitors.

\subsection{Limitations and Future Research}

Although we are able to take advantage of geographic and temporal variation in Craigslist's entry patterns to rule out a number of alternative explanations, a few limitations remain. For example, we observe that newspapers with classified-ad managers are more likely to experience a decline in display-ad rates, but we cannot identify whether this decline is caused by the decrease in newspaper subscribers, as suggested by our model, or because of some small display advertisers substituting away from higherpriced display ads to simple online classified ads after Craigslist's entry. Display advertisers are often less

price-sensitive and care more about their brand image than classified advertisers, however, so we expect the effect from the latter case to be small.

Second, subscribers' substitution away from newspapers to other forms of media, such as Craigslist, may also contribute to the drop in newspaper circulation. This might occur, for example, if a 
portion of the circulation is to individuals who purchase newspapers to search classified ads for temporary-work opportunities. The interdependence of consumer demand and the number of classified ads is more likely to exist for newspapers sold at newsstands. Our focus on yearly subscription prices and circulation data help alleviate this concern. Indeed, empirical studies (e.g., Argentesi and Filistrucchi 2007) using yearly data find no effect of ads on consumer demand for daily newspapers.

Third, the depth of our analysis is limited by data availability, as with any empirical work. While we are able to observe newspapers' prices, we do not have demand data for display or classified advertisers. As a result, we are unable to estimate the impact of Craigslist on newspaper revenues or profits.

Finally, we treat newspapers independent of each other, when in fact many newspapers are owned by the same parent firm. One possibility is that a newspaper with a parent that owns newspapers in other markets which experienced Craigslist's entry may have moved further down the learning curve (Lieberman 1987) and be able to react faster to Craigslist's entry. For example, such newspapers may drop classified-ad rates in anticipation of Craigslist's entry, in an attempt to lock in classified advertisers. To the extent this occurs, it biases against our finding a result, suggesting that the full effect of Craigslist's entry on newspaper classified-ad rates may be understated. A full understanding of how a newspaper group learns from Craigslist's entry is beyond the scope of the current article, but is an area for future research.

\section{References}

Argentesi, Elena, and Lapo Filistrucchi. 2007. "Estimating Market Power in a Two-Sided Market: The Case of Newspapers." Journal of Applied Econometrics 22(7): 1247-1266.

Armstrong, Mark. 2006. "Competition in Two-Sided Markets." RAND Journal of Economics 37(3): 669691.

Athey, Susan, Emilio Calvano, and Joshua Gans. 2010. "Will the Internet Destroy the News Media?" MIT Working Paper.

Bakos, J. Yannis. 1997. "Reducing Buyer Search Costs: Implications for Electronic Marketplaces." Management Science 43(12): 1676-1692.

Berry, Steven T., and Joel Waldfogel. 2001. "Do Mergers Increase Product Variety? Evidence from Radio Broadcasting." Quarterly Journal of Economics 116(3): 1009-1025.

Bertrand, Marianne, Esther Duflo, and Sendhil Mullainathan. 2004. "How Much Should We Trust Differences-in-Differences Estimates?” Quarterly Journal of Economics 119(1): 249-275.

Boudreau, Kevin. 2010. "Open Platform Strategies and Innovation: Granting Access vs. Devolving Control," Management Science 56(10): 1849-1872.

Boudreau, Kevin. Forthcoming. "Let a Thousand Flowers Bloom? An Early Look at Large Numbers of Software "Apps" Developers and Patterns of Innovation." Organization Science.

Boudreau, Kevin, and Karim Lakhani. 2009. "How to Manage Outside Innovation: Competitive Markets or Collaborative Communities?" Sloan Management Review 50(4) 69-76.

Caillaud, Bernard, and Bruno Jullien. 2003. "Chicken and Egg: Competition Among Intermediation Service Providers.” RAND Journal of Economics 34(2): 309-328. 
Cantillon, Estelle, and Pai-Ling Yin. 2010. “Competition Between Exchanges: Lessons From the Battle of the Bund." MIT Working Paper.

Casadesus-Masanell, Ramon and Pankaj Ghemawat. 2006. "Dynamic Mixed Duopoly: A Model Motivated by Linux vs. Windows." Management Science 52(7): 1072-1084.

Casadesus-Masanaell, Ramon, and Feng Zhu. 2010. "Strategies to Fight Ad-Sponsored Rivals." Management Science 56(7): 1484-1499.

Ceccagnoli, Marco, Chris Forman, Peng Huang, and D.J. Wu. Forthcoming. "Co-creation of Value in a Platform Ecosystem: The Case of Enterprise Software." MIS Quarterly.

Chan, Jason, and Anindya Ghose. 2011. "Internet's Dirty Secret: Assessing the Impact of Technology Shocks on the Outbreaks of Sexually Transmitted Diseases." New York University Working Paper.

Chandra, Ambarish. 2009. "Targeted Advertising: The Role of Subscriber Characteristics in Media Markets." Journal of Industrial Economics 57(1): 58-84.

Chandra, Ambarish, and Allan Collard-Wexler. 2009. "Mergers in Two-Sided Markets: An Application to the Canadian Newspaper Industry." Journal of Economics \& Management Strategy 18(4): 10451070 .

Chen, Jianqing, Ming Fan, and Mingzhi Li. 2011. Advertising versus Brokerage Model for Online Trading Platforms. Working paper.

Choi, Jeonghye, and David R. Bell. 2011. "Preference Minorities and the Internet." Journal of Marketing Research 48(4): 670-682.

Corts, Kenneth, and Mara Lederman. 2009. "Software Exclusivity and Indirect Network Effects in the US Home Video Game Industry." International Journal of Industrial Organization 27(2): 121-136.

Economides, Nicholas, and Evangelos Katsamaks. 2006. "Two-Sided Competition of Proprietary vs. Open Source Technology Platforms and the Implications for the Software Industry." Management Science 52(7): 1057-1071.

Ekelund, Robert B. Jr., George S. Ford, and Thomas Koutsky. 2000. "Market Power in Radio Markets: An Empirical Analysis of Local and National Concentration," Journal of Law and Economics 43(1): $157-184$.

Forman, Chris, Anindya Ghose, and Avi Goldfarb. 2009. "Competition Between Local and Electronic Markets: How the Benefit of Buying Online Depends on Where You Live." Management Science 54(1): 47-57.

Forman, Chris, Avi Goldfarb, and Shane Greenstein. Forthcoming. "The Internet and Local Wages: A Puzzle." American Economic Review.

Gentzkow, Matthew. 2007. "Valuing New Goods in a Model with Complementarities: Online Newspapers." American Economic Review 97(3): 713-744.

Gentzkow, Matthew and Jesse M. Shapiro. 2010. "What Drives Media Slant? Evidence From U.S. Daily Newspapers," Econometrica, 78(1): 35-71.

George, Lisa M. 2002. "Ownership Concentration and Product Variety in Daily Newspaper Markets." In Communications Policy and Information Technology: Promises, Problems, Prospects, ed. Lorrie F. Cranor, Shane Greenstein, 235-253. Cambridge: MIT Press.

George, Lisa M. 2007. "What's Fit to Print: The Effect of Ownership Concentration on Product Variety in Daily Newspaper Markets." Information Economics and Policy 19(3-4): 285-303.

George, Lisa M. 2008. "The Internet and the Market for Daily Newspapers." The B.E. Journal of Economic Analysis \& Policy (Advances) 8(1).

George, Lisa M., and Joel Waldfogel. 2003. "Who Affects Whom In Daily Newspaper Markets?” Journal of Political Economy 111(4): 765-784.

George, Lisa M., and Joel Waldfogel. 2006. "The 'New York Times' and the Market for Local Newspapers." American Economic Review 96(1): 435-447.

Godes, David, Elie Ofek, and Miklos Sarvary. 2009. "Content vs. Advertising: The Impact of Competition on Media Firm Strategy." Marketing Science 28(1): 20-35.

Goldmanis, Maris, Ali Hortaçsu, Chad Syverson, and Oönsel Emre. 2010. "E-Commerce and the Market Structure of Retail Industries.” Economic Journal 120(545): 651-682. 
Goldfarb, Avi, and Catherine Tucker. 2011a. "Search Engine Advertising: Pricing Ads to Context." Management Science 57(3): 458-470.

Goldfarb, Avi, and Catherine Tucker. 2011b. "Advertising Bans and the Substitutability of Online and Offline Advertising." Journal of Marketing Research 48(2): 207-227.

Hagiu, Andrei. 2006 "Pricing and Commitment by Two-Sided Platforms," RAND Journal of Economics 37(3), 720-737.

Hagiu, Andrei. 2009. "Two-Sided Platforms: Product Variety and Pricing Structures." Journal of Economics \& Management Strategy 18(4): 1011-1043.

Huang, Peng, Marco Ceccagnoli, Chris Forman, and D.J. Wu. 2011. "When Do ISVs Join a Platform Ecosystem? Evidence from the Enterprise Software Industry." Working paper.

Jackaway, Gwenyth L. 1995. Media at War: Radio's Challenge to the Newspapers, 1924-1939. Westport, CT: Praeger Publishers.

Jin, Ginger Zhe, and Marc Rysman. 2010. "Platform Pricing at Sportscard Conventions." University of Maryland Working Paper.

Kaiser, Ulrich. 2006. "Magazines and Their Companion Websites: Competing Outlet Channels?" Review of Marketing Science 4(3).

Kaiser, Ulrich, and Minjae Song. 2009. "Do Media Consumers Really Dislike Advertising? An Empirical Assessment of the Role of Advertising in Print Media Markets." International Journal of Industrial Organization 27(2): 292-301.

Kroft, Kory, and Devin G. Pope. 2008. "Does Online Search Crowd Out Traditional Search and Improve Matching Efficiency? Evidence from Craigslist." UC Berkeley Working Paper.

Lieberman, Marvin. 1987. "The Learning Curve, Diffusion, and Competitive Strategy." Strategic Management Journal 8(5): 441-452.

Liebowitz, Stan, and Alejandro Zentner. Forthcoming. "Clash of the Titans: Does Internet Use Reduce Television Viewing?" Review of Economics and Statistics.

Nair, Harikesh, Pradeep K. Chintagunta, and Jean-Pierre Dubé. 2004. "Empirical Analysis of Indirect Network Effects in the Market for Personal Digital Assistants." Quantitative Marketing and Economics 2(1): 23-58.

Parker, Geoffrey, and Marshall W. Van Alstyne. 2005. "Two-Sided Network Effects: A Theory of Information Product Design." Management Science 51(10): 1494-1504.

Prince, Jeffrey T. 2007. "The Beginning of Online/Retail Competition and Its Origins: An Application to Personal Computers." International Journal of Industrial Organization 25(1): 139-156.

Rochet, Jean-Charles, and Jean Tirole. 2003. "Platform Competition in Two-Sided Markets." Journal of the European Economic Association, 1(4): 990-1029.

Rysman, Marc. 2009. "The Economics of Two-Sided Markets.” Journal of Economic Perspectives 23(3): $125-144$.

Simon, Daniel, and Vrinda Kadiyali. 2007. "The Effect of a Magazine's Free Digital Content on Its Print Circulation: Cannibalization or Complementarity?" Information Economics and Policy 19(3-4): 344361.

Sweeting, Andrew. 2010. "The Effects of Horizontal Mergers on Product Positioning: Evidence from the Music Radio Industry." RAND Journal of Economics 41(2): 372-397.

Vogel, Harold L. 2011. Entertainment Industry Economics: A Guide for Financial Analysis, $8^{\text {th }}$ ed. Cambridge: Cambridge University Press.

Wallsten, Scott, and Colleen Mallahan. 2010. "Residential Broadband Competition in the United States," Technology Policy Institute working paper.

Weyl, E. Glen. 2010. "A Price Theory of Multi-sided Platforms." American Economic Review 100(4): $1642-1672$.

Wilbur, Kenneth C. 2008. "A Two-Sided, Empirical Model of Television Advertising and Viewing Markets." Marketing Science 27(3): 356-378.

Zentner, Alejandro. 2006. Measuring the Effect of File Sharing on Music Purchases. Journal of Law and Economics 49(1): 63-90. 
Table 1:

Summary Statistics

\begin{tabular}{|c|c|c|c|c|c|}
\hline Variable & Mean & Std. Dev. & Min & Max & Data Source \\
\hline Dummy for Craigslist Entry & 0.08 & 0.28 & 0.00 & 1.00 & Craigslist.org \\
\hline Classified-Ad Rate & 5.55 & 6.31 & 0.11 & 143.00 & SRDS \\
\hline Subscription Price & 118.50 & 44.58 & 5.00 & 443.04 & $\mathrm{E} \& \mathrm{P}$ \\
\hline Circulation & $48,480.57$ & $87,053.28$ & 727 & 1006,130 & E\&P \\
\hline Display-Ad Rate & 44.48 & 64.77 & 3.50 & 490.00 & E\&P \\
\hline Dummy for Classified Manager & 0.35 & 0.48 & 0.00 & 1.00 & $\mathrm{E} \& \mathrm{P}$ \\
\hline Independent & 0.92 & 0.28 & 0.00 & 1.00 & $\mathrm{E} \& \mathrm{P}$ \\
\hline Year Founded & 1887 & 36 & 1764 & 2000 & $\mathrm{E} \& \mathrm{P}$ \\
\hline Number of MIS Positions & 1.03 & 1.28 & 0.00 & 21.00 & E\&P \\
\hline Art Editors & 0.09 & 0.13 & 0.00 & 1.00 & E\&P \\
\hline Business Editors & 0.06 & 0.09 & 0.00 & 1.00 & E\&P \\
\hline Entertainment Editors & 0.05 & 0.09 & 0.00 & 1.00 & E\&P \\
\hline Home Editors & 0.12 & 0.17 & 0.00 & 1.00 & $\mathrm{E} \& \mathrm{P}$ \\
\hline Local Editors & 0.16 & 0.18 & 0.00 & 1.00 & $\mathrm{E} \& \mathrm{P}$ \\
\hline National Editors & 0.01 & 0.06 & 0.00 & 1.00 & $\mathrm{E} \& \mathrm{P}$ \\
\hline Opinion Editors & 0.13 & 0.14 & 0.00 & 1.00 & $\mathrm{E} \& \mathrm{P}$ \\
\hline Special Section Editors & 0.09 & 0.12 & 0.00 & 1.00 & $\mathrm{E} \& \mathrm{P}$ \\
\hline Sports Editors & 0.24 & 0.27 & 0.00 & 1.00 & E\&P \\
\hline Technology Editors & 0.05 & 0.09 & 0.00 & 1.00 & E\&P \\
\hline Age (County) & 36.69 & 3.00 & 23.06 & 54.30 & Census \\
\hline Population (County) & 357,383 & $1,048,498$ & 2,681 & $9,891,484$ & Census \\
\hline Pct. College Degree (County) & 0.13 & 0.05 & 0.03 & 0.40 & Census \\
\hline Per Capita Income (County) & 19,497 & 4,545 & 9,872 & 44,962 & Census \\
\hline Pct. Rental (County) & 0.31 & 0.08 & 0.12 & 0.80 & Census \\
\hline Average Number of ISPs & 3.14 & 2.02 & 0.00 & 16.00 & FCC \\
\hline Number of Posts & 630.52 & 7733.53 & 0.00 & 295,932 & internetarchive.org \\
\hline
\end{tabular}


Table 2:

Comparison of Newspaper Responses Before and After Craigslist's Entry

\begin{tabular}{l|cc|cc|c}
\hline & \multicolumn{2}{|c|}{ With Classified-Ad Manager in Entry Year } & \multicolumn{2}{|c|}{ Without Classified-Ad Manager in Entry Year } & \multirow{2}{*}{ Difference in Differences } \\
\cline { 2 - 5 } & Pre Entry & Post Entry & Pre Entry & Post Entry & $-0.42 * * *$ \\
Classified-Ad Rate & -0.24 & 0.68 & -0.44 & 0.90 & $0.27 * *$ \\
Subscription Price & -0.27 & 0.86 & -0.22 & 0.66 & $-0.20^{* *}$ \\
Circulation Share & 0.41 & -1.02 & 0.28 & -0.95 & -0.08 \\
Display-Ad Rate & -0.37 & 0.92 & -0.33 & 1.04 & \\
\hline
\end{tabular}

Notes: In the last column, we take the difference between post-entry value and pre-entry value for newspapers with a classified-ad manager in Craigslist's entry year and compare it to the difference for those without a classified-ad manager in Craigslist's entry year. Heteroskedasticityadjusted standard errors in parentheses. ${ }^{*}$ significant at $10 \% ; * *$ significant at $5 \%$; *** significant at $1 \%$. 
Table 3:

Impact of Craigslist's Entry on Log Classified-Ad Rate (OLS Models)

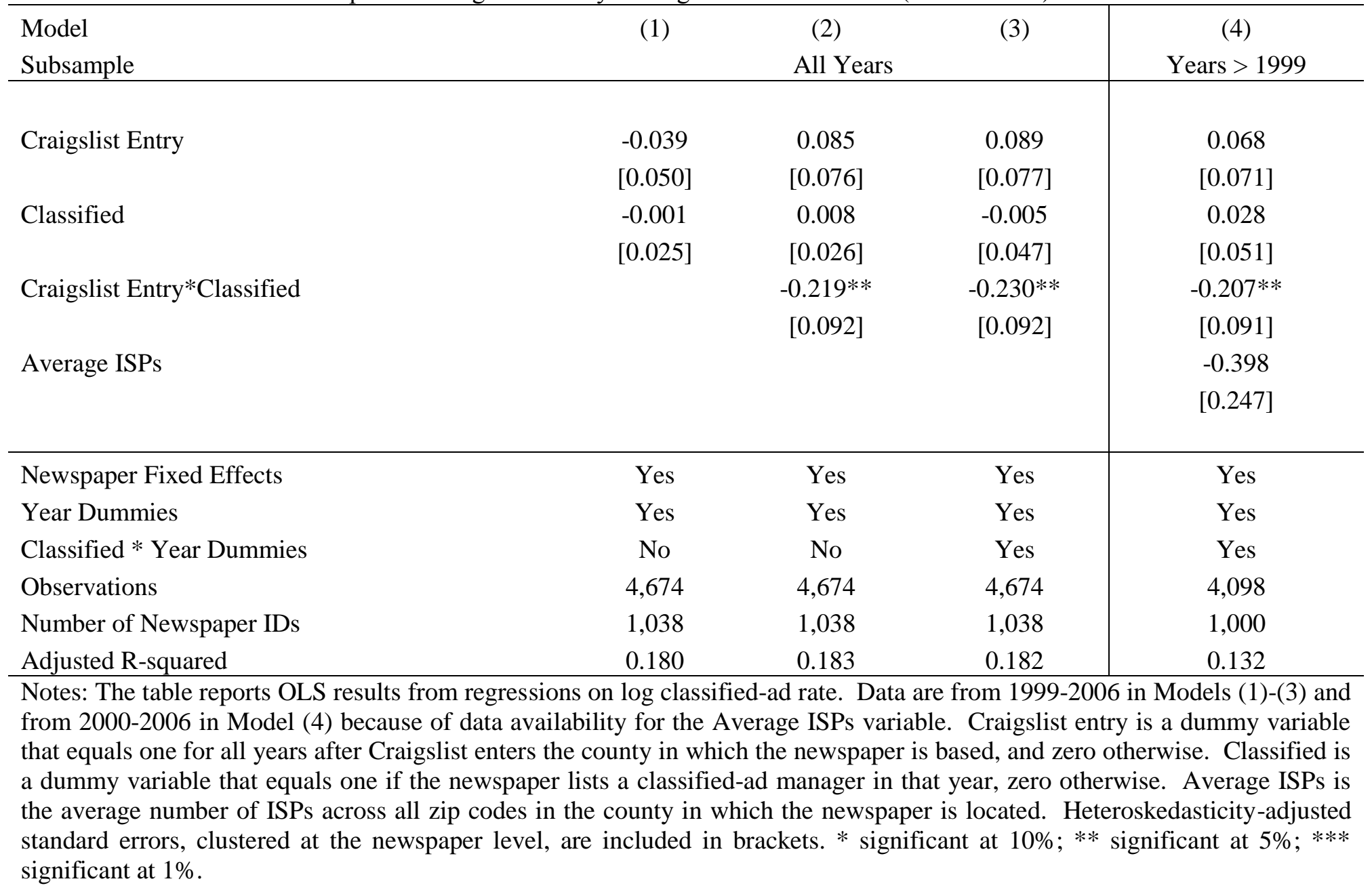


Table 4:

Propagation of the Effect of Craigslist Entry (OLS Models)

\begin{tabular}{|c|c|c|c|c|c|c|}
\hline $\begin{array}{l}\text { Model } \\
\text { Dependent Variable }\end{array}$ & \multicolumn{2}{|c|}{ Log Price } & \multicolumn{2}{|c|}{ Circ Share } & \multicolumn{2}{|c|}{ Log Display-Ad Rate } \\
\hline Craigslist Entry & $\begin{array}{c}-0.020 * * \\
{[0.009]}\end{array}$ & $\begin{array}{c}-0.013 \\
{[0.008]}\end{array}$ & $\begin{array}{c}0.002 \\
{[0.002]}\end{array}$ & $\begin{array}{c}0.000 \\
{[0.001]}\end{array}$ & $\begin{array}{l}0.022^{*} \\
{[0.013]}\end{array}$ & $\begin{array}{c}0.011 \\
{[0.012]}\end{array}$ \\
\hline Classified & $\begin{array}{l}-0.016 \\
{[0.009]}\end{array}$ & $\begin{array}{c}-0.026 * * * \\
{[0.010]}\end{array}$ & $\begin{array}{l}-0.001 \\
{[0.002]}\end{array}$ & $\begin{array}{c}-0.002 \\
{[0.002]}\end{array}$ & $\begin{array}{c}0.006 \\
{[0.012]}\end{array}$ & $\begin{array}{c}0.016 \\
{[0.013]}\end{array}$ \\
\hline Craigslist Entry*Classified & $\begin{array}{c}0.026^{* *} \\
{[0.012]}\end{array}$ & $\begin{array}{c}0.033 * * * \\
{[0.011]}\end{array}$ & $\begin{array}{c}-0.008 * * \\
{[0.003]}\end{array}$ & $\begin{array}{c}-0.006^{* *} \\
{[0.003]}\end{array}$ & $\begin{array}{l}-0.009 \\
{[0.016]}\end{array}$ & $\begin{array}{c}-0.031 * * \\
{[0.015]}\end{array}$ \\
\hline Average ISPs & & $\begin{array}{c}0.072 * * \\
{[0.034]}\end{array}$ & & $\begin{array}{c}-0.043 * * \\
{[0.019]}\end{array}$ & & $\begin{array}{c}-0.126^{* *} \\
{[0.053]}\end{array}$ \\
\hline Newspaper Fixed Effects & Yes & Yes & Yes & Yes & Yes & Yes \\
\hline Year Dummies & Yes & Yes & Yes & Yes & Yes & Yes \\
\hline Classified $*$ Year Dummies & Yes & Yes & Yes & Yes & Yes & Yes \\
\hline Observations & 8,937 & 6,802 & 5,938 & 4,427 & 6,460 & 4,918 \\
\hline Number of Newspaper IDs & 2,086 & 1,961 & 1,576 & 1,454 & 1,617 & 1,500 \\
\hline Adjusted R-squared & 0.131 & 0.113 & 0.226 & 0.256 & 0.471 & 0.328 \\
\hline
\end{tabular}

Notes: The table reports OLS results from regressions on log price, circulation share and log display-ad rate. Data are from 1999-2007 in Models 1, 3, 5 and from 2000-2007 in Models 2, 4, 6 because of data availability for the Average ISPs variable. Craigslist entry is a dummy variable that equals one for all years after Craigslist enters the county in which the newspaper is based, and zero otherwise. Classified is a dummy variable that equals one if the newspaper lists a classified-ad manager in that year, zero otherwise. Average ISPs is the average number of ISPs across all zip codes in the county in which the newspaper is located. Heteroskedasticity-adjusted standard errors, clustered at the newspaper level, are included in brackets. * significant at 10\%; ** significant at 5\%; *** significant at $1 \%$. 
Table 5:

Determinants of Craigslist Entry (Hazard Model; Marginal Effects Reported)

\begin{tabular}{|c|c|c|c|}
\hline Model & (1) & $(2)$ & (3) \\
\hline \multirow[t]{2}{*}{ Age } & 0.001 & 0.001 & 0.001 \\
\hline & {$[0.001]$} & [0.001] & {$[0.000]$} \\
\hline \multirow[t]{2}{*}{ Population } & $0.001 * * *$ & $0.001 * * *$ & $0.001 * * *$ \\
\hline & {$[0.000]$} & {$[0.000]$} & {$[0.000]$} \\
\hline \multirow[t]{2}{*}{ Pct. College Degree } & $0.158 * *$ & $0.156^{* *}$ & $0.136 * *$ \\
\hline & {$[0.071]$} & [0.069] & {$[0.056]$} \\
\hline \multirow[t]{2}{*}{ Pct. Black } & -0.008 & -0.008 & -0.010 \\
\hline & [0.011] & [0.011] & [0.011] \\
\hline \multirow[t]{2}{*}{ Per Capita Income } & -0.070 & -0.067 & -0.063 \\
\hline & [0.047] & {$[0.045]$} & [0.039] \\
\hline \multirow[t]{2}{*}{ Pct. Rental } & $0.093 * *$ & $0.092 * *$ & $0.081 * *$ \\
\hline & {$[0.042]$} & {$[0.041]$} & {$[0.034]$} \\
\hline \multirow[t]{2}{*}{ Number ISPs } & $-0.069 *$ & $-0.068 *$ & $-0.051 *$ \\
\hline & {$[0.038]$} & [0.038] & [0.029] \\
\hline \multirow[t]{2}{*}{ Number of Papers } & & -0.000 & -0.000 \\
\hline & & {$[0.001]$} & {$[0.001]$} \\
\hline \multirow[t]{2}{*}{ Independent } & & 0.005 & 0.005 \\
\hline & & {$[0.004]$} & {$[0.003]$} \\
\hline \multirow[t]{2}{*}{ Newspaper Age } & & -0.000 & -0.000 \\
\hline & & {$[0.000]$} & {$[0.000]$} \\
\hline \multirow[t]{2}{*}{ Classified } & & & 0.003 \\
\hline & & & {$[0.002]$} \\
\hline \multirow[t]{2}{*}{ Number MIS Positions } & & & 0.002 \\
\hline & & & {$[0.001]$} \\
\hline \multirow[t]{2}{*}{ Total Number of Positions } & & & 0.001 \\
\hline & & & {$[0.000]$} \\
\hline Year Dummies & Yes & Yes & Yes \\
\hline Observations & 4,155 & 4,155 & 4,155 \\
\hline Pseudo R-squared & 0.534 & 0.535 & 0.545 \\
\hline \multicolumn{4}{|c|}{$\begin{array}{l}\text { Notes: The table reports linear probability results from a hazard model predicting } \\
\text { Craigslist's entry into a county. The dependent variable equals one when the county } \\
\text { experiences Craigslist's entry, zero otherwise. Craigslist's entry is an absorbing state } \\
\text { so the county is dropped from the sample in the years after the dependent variable } \\
\text { becomes one. The controls include demographic variables at the county level and } \\
\text { newspaper characteristics which have been averaged across all the newspapers in the } \\
\text { county. Heteroskedasticity-adjusted standard errors are included in brackets. * } \\
\text { significant at } 10 \% \text {; ** significant at } 5 \% \text {; *** significant at } 1 \% \text {. }\end{array}$} \\
\hline
\end{tabular}


Table 6:

Falsification Check: Difference Between Affected Newspapers and Other Newspapers before Craigslist's Entry (OLS Models)

\begin{tabular}{|c|c|c|c|c|}
\hline Model & (1) & (2) & (3) & (4) \\
\hline Dependent Variable & Log Classified-Ad Rate & Log Price & Circ Share & Log Display-Ad Rate \\
\hline \multirow[t]{2}{*}{ Classified } & 0.019 & $-0.034 * * *$ & -0.001 & 0.010 \\
\hline & {$[0.054]$} & [0.011] & {$[0.002]$} & [0.016] \\
\hline \multirow[t]{2}{*}{ Eventual Entry*Classified } & 0.005 & 0.015 & -0.003 & 0.018 \\
\hline & {$[0.062]$} & [0.011] & {$[0.003]$} & {$[0.018]$} \\
\hline \multirow[t]{2}{*}{ Average ISPs } & $-0.414^{*}$ & $0.061 *$ & $-0.037^{*}$ & -0.080 \\
\hline & [0.248] & [0.036] & [0.019] & [0.059] \\
\hline Newspaper Fixed Effects & Yes & Yes & Yes & Yes \\
\hline Year Dummies & Yes & Yes & Yes & Yes \\
\hline Classified $*$ Year Dummies & Yes & Yes & Yes & Yes \\
\hline Observations & 3,905 & 6,097 & 3,884 & 4,359 \\
\hline Number of Newspaper IDs & 978 & 1,892 & 1,404 & 1,457 \\
\hline Adjusted R-squared & 0.132 & 0.106 & 0.243 & 0.273 \\
\hline \multicolumn{5}{|c|}{$\begin{array}{l}\text { Notes: The table reports OLS results from regressions on log classified-ad rate, log price, circulation share and log display-ad rate. Classified } \\
\text { is a dummy variable that equals one if the newspaper lists a classified-ad manager in that year, zero otherwise. Eventual entry is a dummy } \\
\text { variable that equals one for all newspapers that ever experience entry by Craigslist into their county, and zero otherwise. Its main effect is } \\
\text { absorbed by newspaper fixed-effects. Average ISPs is the average number of ISPs across all zip codes in the county in which the newspaper is } \\
\text { located. Heteroskedasticity-adjusted standard errors, clustered at the newspaper level, are included in brackets. * significant at } 10 \% \text {; } * * \\
\text { significant at 5\%; *** significant at } 1 \% \text {. }\end{array}$} \\
\hline
\end{tabular}


Table 7:

Robustness Check: Use Number of Posts to Measure Diffusion of Craigslist (OLS Models)

\begin{tabular}{|c|c|c|c|c|}
\hline Model & $(1)$ & (2) & (3) & (4) \\
\hline Dependent Variable & Log Classified-Ad Rate & Log Price & Circ Share & Log Display-Ad Rate \\
\hline \multirow[t]{2}{*}{ Number of Posts } & 0.008 & -0.001 & 0.000 & 0.002 \\
\hline & {$[0.005]$} & {$[0.001]$} & {$[0.000]$} & {$[0.002]$} \\
\hline \multirow[t]{2}{*}{ Classified } & 0.027 & $-0.030^{* * *}$ & -0.003 & 0.019 \\
\hline & {$[0.052]$} & {$[0.010]$} & [0.002] & {$[0.014]$} \\
\hline \multirow[t]{2}{*}{ Number of Posts*Classified } & $-0.019 * *$ & $0.004 * *$ & $-0.001 * * *$ & $-0.005^{*}$ \\
\hline & {$[0.008]$} & {$[0.002]$} & {$[0.000]$} & {$[0.002]$} \\
\hline \multirow[t]{2}{*}{ Average ISPs } & -0.384 & $0.069^{* *}$ & $-0.041 * *$ & $-0.123^{*}$ \\
\hline & {$[0.248]$} & {$[0.034]$} & [0.019] & {$[0.053]$} \\
\hline Newspaper Fixed Effects & Yes & Yes & Yes & Yes \\
\hline Year Dummies & Yes & Yes & Yes & Yes \\
\hline Classified * Year Dummies & Yes & Yes & Yes & Yes \\
\hline Observations & 4,061 & 6,735 & 4,367 & 4,858 \\
\hline Number of Newspaper IDs & 995 & 1,953 & 1,443 & 1,487 \\
\hline Adjusted R-squared & 0.130 & 0.115 & 0.253 & 0.327 \\
\hline \multicolumn{5}{|c|}{$\begin{array}{l}\text { Notes: The table reports OLS results from regressions on log classified-ad rate, log price, circulation share and log display-ad rate. Number o } \\
\text { posts is a count of the average number of posts on the local Craigslist website across the year. Classified is a dummy variable that equals one i } \\
\text { the newspaper lists a classified-ad manager in that year, zero otherwise. Average ISPs is the average number of ISPs across all zip codes in th } \\
\text { county in which the newspaper is located. Heteroskedasticity-adjusted standard errors, clustered at the newspaper level, are included i } \\
\text { brackets. } * \text { significant at } 10 \% ; * * \text { significant at } 5 \% ; * * * \text { significant at } 1 \% \text {. }\end{array}$} \\
\hline
\end{tabular}


Table 8:

Robustness Check: Normalize Classified Dummy with Total Number of Managerial Positions (OLS Models)

\begin{tabular}{|c|c|c|c|c|}
\hline Model & (1) & (2) & (3) & (4) \\
\hline Dependent Variable & Log Classified-Ad Rate & Log Price & Circ Share & Log Display-Ad Rate \\
\hline \multirow[t]{2}{*}{ Craigslist Entry } & 0.068 & -0.011 & 0.001 & 0.012 \\
\hline & {$[0.071]$} & {$[0.008]$} & [0.001] & {$[0.012]$} \\
\hline \multirow[t]{2}{*}{ Classified } & 0.018 & $-0.035^{* *}$ & 0.002 & $0.043 * *$ \\
\hline & {$[0.048]$} & {$[0.014]$} & {$[0.002]$} & {$[0.021]$} \\
\hline \multirow[t]{2}{*}{ Craigslist Entry*Classified } & $-0.206^{* *}$ & $0.026 * *$ & $-0.008 * *$ & $-0.033 * *$ \\
\hline & {$[0.091]$} & {$[0.011]$} & {$[0.003]$} & {$[0.015]$} \\
\hline \multirow[t]{2}{*}{ Average ISPs } & -0.399 & $0.075^{* *}$ & $-0.042 * *$ & $-0.128 * *$ \\
\hline & {$[0.247]$} & {$[0.034]$} & [0.019] & {$[0.052]$} \\
\hline Newspaper Fixed Effects & Yes & Yes & Yes & Yes \\
\hline Year Dummies & Yes & Yes & Yes & Yes \\
\hline Classified * Year Dummies & Yes & Yes & Yes & Yes \\
\hline Observations & 4,098 & 6,802 & 4,427 & 4,918 \\
\hline Number of Newspaper IDs & 1,000 & 1,961 & 1,454 & 1,500 \\
\hline Adjusted R-squared & 0.131 & 0.112 & 0.256 & 0.329 \\
\hline \multicolumn{5}{|c|}{$\begin{array}{l}\text { Notes: The table reports OLS results from regressions on log classified-ad rate, log price, circulation share and log display-ad rate. Craigslis } \\
\text { entry is a dummy variable that equals one for all years after Craigslist enters the county in which the newspaper is based, and zero otherwise } \\
\text { Classified is one divided by the total number of managerial positions listed for the newspaper in that year if the newspaper lists a classified } \\
\text { ad manager in that year, zero otherwise. Average ISPs is the average number of ISPs across all zip codes in the county in which the } \\
\text { newspaper is located. Heteroskedasticity-adjusted standard errors, clustered at the newspaper level, are included in brackets. * significant a } \\
10 \% \text {; ** significant at 5\%; *** significant at } 1 \% \text {. }\end{array}$} \\
\hline
\end{tabular}


Table 9:

Robustness Check: Fix Classified Dummy Using Its Value in Year 2000 (OLS Models)

\begin{tabular}{|c|c|c|c|c|}
\hline Model & (1) & (2) & (3) & (4) \\
\hline Dependent Variable & Log Classified-Ad Rate & Log Price & Circ Share & Log Display-Ad Rate \\
\hline \multirow[t]{2}{*}{ Craigslist Entry } & 0.021 & -0.014 & 0.001 & 0.023 \\
\hline & {$[0.053]$} & [0.009] & {$[0.002]$} & {$[0.015]$} \\
\hline \multirow[t]{2}{*}{ Craigslist Entry*Classified } & $-0.196 * *$ & $0.034 * *$ & $-0.006^{* *}$ & $-0.036^{*}$ \\
\hline & {$[0.096]$} & {$[0.016]$} & {$[0.003]$} & {$[0.020]$} \\
\hline \multirow[t]{2}{*}{ Average ISPs } & -0.014 & $0.074 * *$ & $-0.036^{*}$ & $-0.109^{*}$ \\
\hline & [0.192] & {$[0.037]$} & {$[0.021]$} & {$[0.056]$} \\
\hline Newspaper Fixed Effects & Yes & Yes & Yes & Yes \\
\hline Year Dummies & Yes & Yes & Yes & Yes \\
\hline Classified*Year Dummies & Yes & Yes & Yes & Yes \\
\hline Observations & 3,428 & 4,932 & 3,101 & 3,573 \\
\hline Number of Newspaper IDs & 762 & 1,510 & 1,076 & 1,144 \\
\hline Adjusted R-squared & 0.095 & 0.099 & 0.249 & 0.307 \\
\hline
\end{tabular}


Table 10:

Robustness Check: Include Number of Competitors in Market (OLS Models)

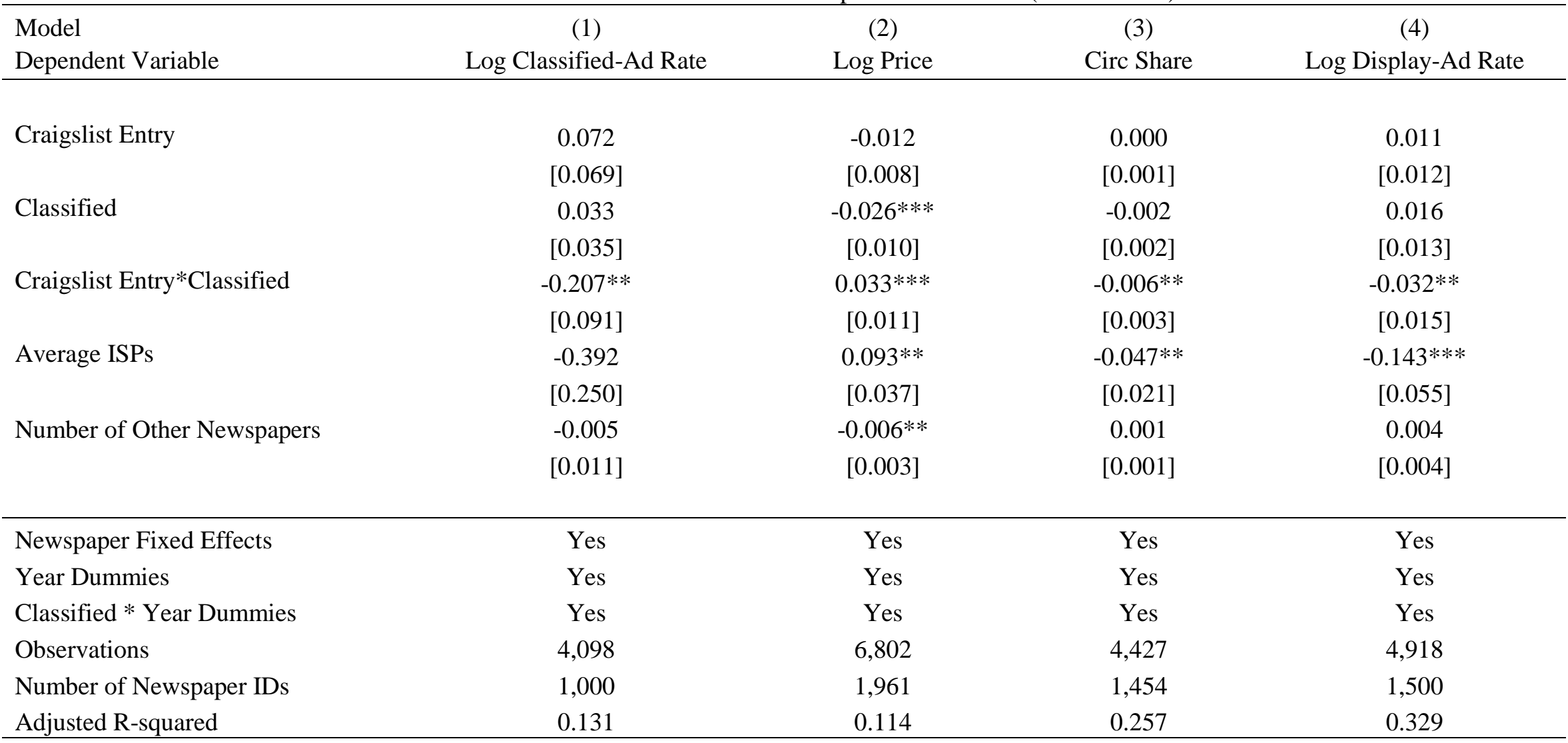

Notes: The table reports OLS results from regressions on log classified-ad rate, log price, circulation share and log display-ad rate. Craigslist entry is a dummy variable that equals one for all years after Craigslist enters the county in which the newspaper is based, and zero otherwise. Classified is a dummy variable that equals one if the newspaper lists a classified-ad manager in that year, zero otherwise. Average ISPs is the average number of ISPs across all zip codes in the county in which the newspaper is located. Number of Other Newspapers is a count of the number of other newspapers in the county in which the focal newspaper is located. Heteroskedasticity-adjusted standard errors, clustered at the newspaper level, are included in brackets. * significant at $10 \%$; ** significant at 5\%; *** significant at $1 \%$. 
Table 11:

Robustness Check: Effect of Craigslist Entry on Newspaper Editor Type (OLS Models)

\begin{tabular}{|c|c|c|c|c|c|c|c|c|c|c|c|}
\hline Model & (1) & (2) & (3) & (4) & (5) & (6) & (7) & (8) & (9) & (10) & (11) \\
\hline Dependent Variable & $\begin{array}{c}\text { Total } \\
\text { Positions }\end{array}$ & Art & Business & Ent. & Home & Local & National & Opinion & Special & Sports & Tech \\
\hline \multirow[t]{2}{*}{ Craigslist Entry } & 0.111 & 0.001 & -0.003 & 0.004 & 0.005 & 0.000 & -0.001 & 0.016 & $0.027 * *$ & $-0.040 * * *$ & -0.007 \\
\hline & {$[0.094]$} & [0.009] & {$[0.005]$} & {$[0.006]$} & {$[0.006]$} & {$[0.008]$} & {$[0.001]$} & {$[0.008]$} & {$[0.013]$} & {$[0.014]$} & [0.006] \\
\hline \multirow{2}{*}{ Classified } & $0.322 * * *$ & 0.001 & $0.010 * *$ & $0.015 * * *$ & $0.011^{*}$ & 0.005 & 0.000 & 0.007 & $-0.019 *$ & $-0.029 *$ & -0.002 \\
\hline & [0.094] & {$[0.007]$} & {$[0.005]$} & {$[0.005]$} & {$[0.007]$} & {$[0.007]$} & {$[0.001]$} & [0.008] & {$[0.011]$} & {$[0.015]$} & [0.006] \\
\hline \multirow[t]{2}{*}{ Craigslist Entry*Classified } & 0.008 & 0.007 & 0.009 & -0.001 & -0.012 & 0.007 & 0.003 & -0.003 & -0.026 & 0.011 & 0.005 \\
\hline & [0.147] & {$[0.012]$} & {$[0.009]$} & {$[0.009]$} & {$[0.011]$} & {$[0.011]$} & {$[0.004]$} & [0.016] & {$[0.016]$} & {$[0.020]$} & [0.009] \\
\hline \multirow[t]{2}{*}{ Average ISPs } & -0.193 & -0.035 & $0.024^{*}$ & 0.039 & 0.027 & 0.020 & -0.005 & 0.035 & -0.058 & -0.045 & -0.001 \\
\hline & {$[0.337]$} & {$[0.030]$} & [0.014] & {$[0.026]$} & {$[0.032]$} & [0.024] & [0.004] & {$[0.032]$} & [0.037] & {$[0.051]$} & [0.020] \\
\hline Newspaper Fixed Effects & Yes & Yes & Yes & Yes & Yes & Yes & Yes & Yes & Yes & Yes & Yes \\
\hline Year Dummies & Yes & Yes & Yes & Yes & Yes & Yes & Yes & Yes & Yes & Yes & Yes \\
\hline Year*Classified Dummies & Yes & Yes & Yes & Yes & Yes & Yes & Yes & Yes & Yes & Yes & Yes \\
\hline Observations & 6,504 & 6,504 & 6,504 & 6,504 & 6,504 & 6,504 & 6,504 & 6,504 & 6,504 & 6,504 & 6,504 \\
\hline Number of Newspaper IDs & 2,036 & 2,036 & 2,036 & 2,036 & 2,036 & 2,036 & 2,036 & 2,036 & 2,036 & 2,036 & 2,036 \\
\hline Adjusted R-squared & 0.064 & 0.003 & 0.020 & 0.004 & 0.006 & 0.013 & 0.000 & 0.019 & 0.002 & 0.023 & 0.013 \\
\hline
\end{tabular}

Notes: The table reports OLS results from regressions on several dependent variables that capture targeting. The dependent variable in Model (1) is a count of the total number of editor types at the newspaper. The dependent variables in Models (2)-(11) are shares of different types of editors at each newspaper. Craigslist entry is a dummy variable that equals one for all years after Craigslist enters the county in which the newspaper is based, and zero otherwise. Classified is a dummy variable that equals one if the newspaper lists a classified-ad manager in that year, zero otherwise. Average ISPs is the average number of ISPs across all zip codes in the county in which the newspaper is located. Heteroskedasticity-adjusted standard errors, clustered at the newspaper level, are included in brackets. * significant at $10 \%$; ** significant at $5 \%$; *** significant at $1 \%$. 
Figure 1:

Number of Craigslist's New Markets in US, Annual

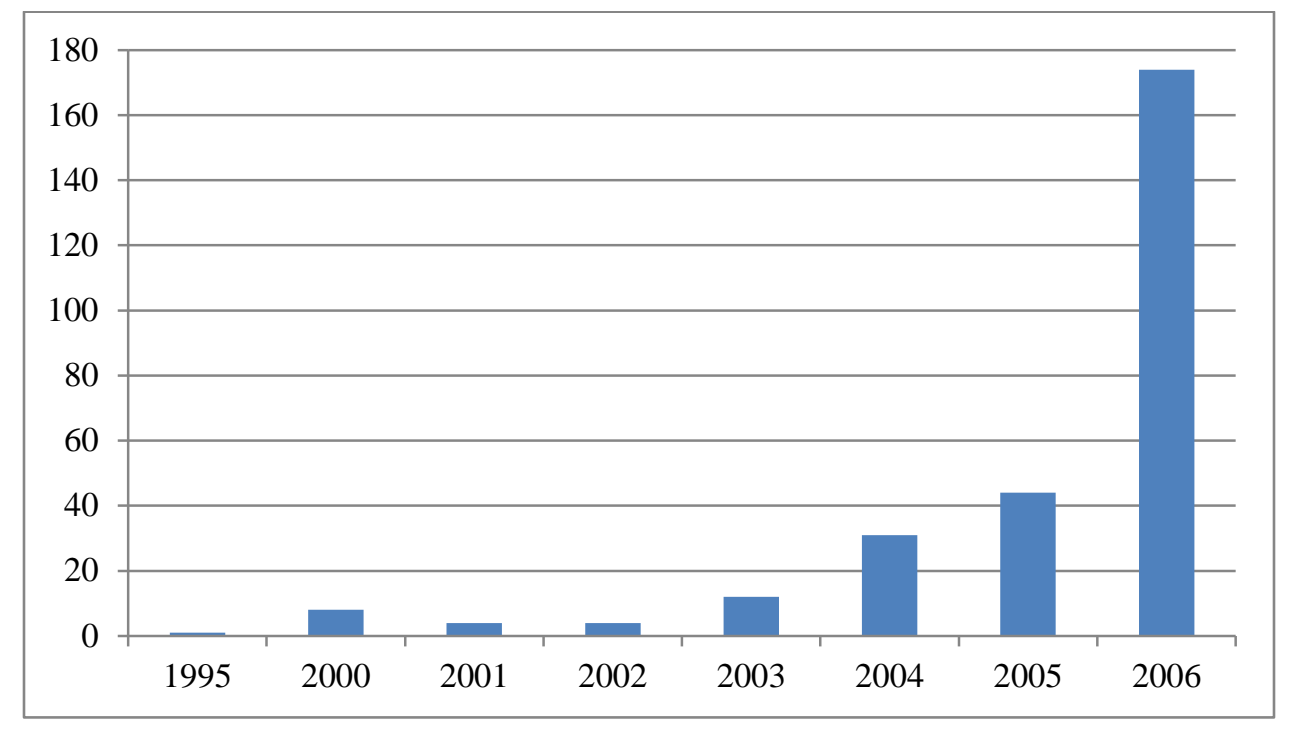

This figure shows the number of new US markets Craigslist entered from 1995-2006. Over this time period, in total Craigslist entered 278 markets in the US. Source: http://www.craigslist.org/about/expansion, last accessed July 2011. 
Figure 2:

Boston Craigslist from February 2003

\begin{tabular}{|c|c|c|c|}
\hline craigslist & \multicolumn{2}{|l|}{ boston } & other craigslists $\vee$ go \\
\hline \multirow{2}{*}{$\frac{\text { place a free classified }}{\underline{\text { listing on craigslist }}}$} & community & housing & (resumes) \\
\hline & events / classes (99) & apts / housing (3029) & arts / media jobs (67) \\
\hline \multirow{2}{*}{$\underline{\text { help }} \quad \underline{\text { subscriptions }}$} & activity partners (412) & apts - broker (1420) & business jobs (268) \\
\hline & artists / musicians (634) & rooms / shared (2980) & computer jobs (91) \\
\hline \multirow[t]{2}{*}{ search craigslist } & gen'l community (516) & sublet / temp / vac (1016) & \multirow{2}{*}{$\begin{array}{l}\text { engineer'g / science (24) } \\
\text { healthcare jobs (35) }\end{array}$} \\
\hline & discussion forums (105683) & office / commercial (101) & \\
\hline community $v$ & & real estate for sale (157) & legal/government (8) \\
\hline search & personals & housing wanted $(735)$ & nonprofit / teaching (115) \\
\hline \multirow[b]{2}{*}{ Solutions at Work } & women seeking men (237) & & office / admin (87) \\
\hline & women seek'g women (163) & sale / wanted & retail / food (15) \\
\hline \multirow{3}{*}{$\begin{array}{l}\text { wishlist program for } \\
\text { schools \& nonprofits }\end{array}$} & men seeking women (832) & general for sale (2725) & et cetera jobs (159) \\
\hline & men seeking men (478) & cars / trucks (1071) & part time jobs new \\
\hline & missed connections (852) & computer / tech (843) & \multirow{4}{*}{ services offered (1472) } \\
\hline \multirow{3}{*}{$\begin{array}{l}\text { terms of use priwacy policy } \\
\text { about us cortart us }\end{array}$} & casual encounters (2156) & furniture (1211) & \\
\hline & & tickets (595) & \\
\hline & & items wanted (730) & \\
\hline
\end{tabular}

This figure is a screen shot of craigslist.org for the Boston market from February 2003, as captured by internetarchive.org. Source: http://web.archive.org/web/20030129082927/boston.craigslist.org/, last accessed July 2011. 
Figure 3:

Chicago Craigslist from February 2003

\begin{tabular}{|c|c|c|c|}
\hline craigslist & \multicolumn{2}{|l|}{ chicago } & \begin{tabular}{|l|l|} 
other craigslists $\vee$ & go \\
\end{tabular} \\
\hline \multirow{2}{*}{$\begin{array}{c}\text { place a free classified } \\
\text { listing on craigslist }\end{array}$} & community & housing & (resumes) \\
\hline & events / classes (22) & apts / housing (456) & arts / media jobs (27) \\
\hline \multirow{2}{*}{$\underline{\text { help }}$ subscriptions } & activity partners (64) & rooms / shared (238) & $\underline{\text { business jobs }(123)}$ \\
\hline & artists / musicians (183) & sublet / temp / vac $(290)$ & computer jobs (69) \\
\hline \multirow{3}{*}{ search craigslist } & gen'l community (222) & office / commercial (12) & engineer'g/ science (7) \\
\hline & discussion forums (18019) & real estate for sale (54) & healthcare jobs ( 8 ) \\
\hline & & housing wanted (113) & legal / government (5) \\
\hline \multirow[t]{2}{*}{ community $v$} & personals & & nonprofit / teaching (25) \\
\hline & women seeking men (39) & sale / wanted & office / admin (28) \\
\hline \multirow{3}{*}{$\begin{array}{l}\frac{\text { wishlist program for }}{\text { schools \& nonprofits }} \\
\text { schen }\end{array}$} & women seek'g women (20) & general for sale (425) & retail / food (11) \\
\hline & men seeking women $(100)$ & cars / trucks $(127)$ & et cetera jobs $(49)$ \\
\hline & men seeking men (120) & computer / tech (115) & part time jobs new \\
\hline \multirow[b]{2}{*}{$\begin{array}{l}\text { terms of use privacy policy } \\
\frac{\text { about us }}{\text { contact us }} \\
\text { (a) } 2003 \text { craigstist }\end{array}$} & missed connections $(105)$ & furniture $(170)$ & \\
\hline & 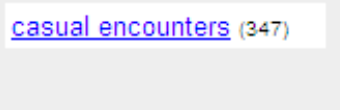 & items wanted (188) & services offered $(474)$ \\
\hline
\end{tabular}

This figure is a screen shot of craigslist.org for the Chicago market from February 2003, as captured by internetarchive.org. Source: http://web.archive.org/web/20030205062029/http://chicago.craigslist.org/, last accessed July 2011. 
Supplementary Appendix:

Correlation between Classified Ad Pages and Classified Manager Dummy (OLS Models)

Model

Classified

Total Number of Pages
(1)

$$
6.668 * * *
$$$$
\text { [1.291] }
$$

(2)

$$
2.806^{* *}
$$

$0.278 * * *$

[0.037]
(3)

$2.556^{* *}$

$0.280 * * *$

[0.035]

\begin{tabular}{lccc}
\hline Year Dummies & No & No & Yes \\
Observations & 93 & 93 & 93 \\
Adjusted R-squared & 0.041 & 0.751 & 0.763 \\
\hline
\end{tabular}

Notes: The table reports OLS results from regressions of the number of classified-ad pages on the classified-ad manager dummy from a group of newspapers for years 1999-2006. The newspapers, which were chosen because of data availability, include: Albany Times Union, Baltimore Morning Sun, Boston Globe, Cincinnati Enquirer, Cleveland Plain Dealer, Dallas Morning News, Denver Post, Detroit News, Houston Chronicle, Indianapolis Star, Kansas City Times-Star, Louisville Courier Journal, New Orleans Times Picayune, Oregonian, Rochester Democrat and Chronicle, and St. Louis Post Dispatch. Counts of the number of classified ad pages and total number of pages in the newspapers were hand collected for each quarter of each year, then averaged across the year. Classified is a dummy variable that equals one if the newspaper lists a classified-ad manager in that year, zero otherwise, according to Editor \& Publisher International Yearbook. Heteroskedasticity-adjusted standard errors are included in brackets. * significant at $10 \%$; ** significant at $5 \%$; *** significant at $1 \%$. 